УДК 378.07:005.53

DOI:

Інна Шоробура, доктор педагогічних наук, професор, ректор Хмельницької гуманітарно-педагогічної академії

\title{
СУЧАСНІ ВИМОГИ ДО УПРАВЛІНСЬКОГО РІШЕННЯ
}

У статті розкрито сучасні вимоги до прийняття управлінського рішення. Визначено особливості управлінських рімень (иілі, наслідки, поділ праці, професіоналізм), основні принципи (системності, стандартизації, оптимальної інформованості, свободи вибору, творчості, відповідальності та ін.). Виділено n'ять стадій творчого вирішення проблеми. Акцентовано на основних етапах процесу прийняття управлінського рішення. Зокрема, ие визначення проблеми, формування иілей, збір інформаиії, розробка проекту рішення, оцінка варіантів, правове оформлення, розробка заходів, контроль за виконанням рішення та ін. Звернено увагу на альтернативні рішення, критерії оцінки.

Ключові слова: управлінське рішення; особливості управлінських рішень; принщипи прийняття управлінських рішень; етапи прийняття управлінських рімень.

Jim. 5.

Inna Shorobura, Doctor of Sciences (Pedagogy), Professor, Rector of Khmelnytsk Humanitarian-Pedagogical Academy

\section{MODERN REQUIREMENTS CONCERNING MANAGERIAL DECISION}

The article presents the modern requirements of making the managerial decisions. Managerial decision is the choice of an alternative made by the decision-maker within the framework of his authority and competencies aimed at achieving the goals of the organization. Managerial decision (individual or group) defines the program of the team work to solve the problem effectively, based on knowledge of objective laws of a managed system functioning and analysis of information about its status. The development of effective managerial decisions is a necessary factor for ensuring the competitiveness of products and organizations in the market, forming rational organizational structures, the implementation of a proper personnel policy, regulation of socio-psychological relations in the organization, creation of its positive image. The peculiarities of managerial decisions (goals, consequences, division of labor, professionalism), basic principles (systematic, standardization, optimal awareness, freedom of choice, creativity, responsibility, etc.) are determined. Five stages of creative problem solving are defined. The decisionmaking process is complex and multilateral. It includes a great number of stages and activities. The questions of how many stages and which stages should pass the decision-making process, what is the specific content of each of them are controversial and can be solved by managers differently. It depends on the qualifications of the manager, the situation, the style of management and culture of the educational institution. It is important for each manager to understand the strengths and limitations of each approach and decision-making procedure and to be able to choose the best option, taking into account the situation and his own management style. The classic approach to making managerial decisions is to follow a certain procedure and to perform compulsory actions. The author focuses on the main stages of the managerial decision-making process. In particular, it is the definition of the problem, the forming of goals, information gaining, the development of a draft decision, assessment of options, legal design, development of measures, control over the implementation of the decision, etc. Attention is paid to alternative solutions and evaluation criteria. The criteria for evaluating the desired solution is the effectiveness of the implementation, the simplicity of achieving the goal, the degree of consideration of the entire production situation, the completeness of the use of resource, the tasks' fulfilment in the specified time, as well as the cost-effectiveness of the solution.

Keywords: managerial decision; the peculiarities of managerial decisions; the principles of making managerial decisions; the stages of making managerial decisions.

$\Pi$ остановка проблеми в загальному вигляді. Перехід до ринкової економіки вимагає нових підходів до управління: на перший план виходять ринкові критерії ефективності і підвищуються вимоги до гнучкості управління. В даний час економічне середовище, в силу своєї нестабільності і рухливості, вимагає нових методів управління, що відповідають рівню сучасних виробничих систем. Як показує практика, на перший план висуваються питання ефективності діяльності організації, безпосередньо пов'язані 3 якісною підготовкою управлінських рішень. Це визначає важливість оволодіння кожним фахівцем в галузі управління теоретичними знаннями і практичними навичками розробки управлінських рішень.

Менеджмент як систематичне наукове дослідження проблем управління сформувався на початку XX ст. У наш час важко назвати білыш важливу і багатогранну сферудіяльності, ніж управління, від якого в значній мірі залежать і ефективність виробництва, i якість обслуговування населення. 
В Україні поки ще не досягнуто значних успіхів в теоретичному i практичному освоєнні менеджменту. Реорганізовуються старі структури управління і влади, при цьому використовуються західні моделі управління. Однак механічне перенесення концепції управління 3 одного соціокультурного середовища в інше, сліпе копіювання досвіду тієї або іншої держави практично неможливе i веде до важких економічних і соціальних наслідків. Тому управлінська освіта в Україні потребує створення системи підготовки кваліфікованих кадрів для роботи в діловому середовищі [1].

Однією з основних функцій управління в даний час $є$ прийняття рішень.

Прийняття рішень - складова частина будьякої управлінської функції. Необхідність прийняття рішення пронизує все, що робить керівник, формуючи цілі і домагаючись їх досягнення. Тому розуміння природи прийняття рішень надзвичайно важливе для кожного, хто хоче досягти успіху в мистецтві управління.

Ефективне прийняття рішень необхідне для виконання управлінських функцій. Удосконалення процесу прийняття обгрунтованих об'єктивних рішень у ситуаціях виняткової складності досягається шляхом використання наукового підходу до даного процесу, моделей і кількісних методів прийняття рішень.

Аналіз останніх досліджень і публікацій. У сучасних наукових дослідженнях розкрито основні підходи до прийняття рішень, визначено методи та способи їх прийняття, звертається увага на контроль за прийняттям рішень (Л. Даниленко, Л. Карамушка, І. Мороз, М. Мурашко, І. Шоробура та ін.).

Ряд науковців досліджують такі етапи прийняття управлінських рішень, як організація, мотивація, контроль (М. Мескон, М. Альберт, Ф. Ходоурі та ін.) [3].

Психологічним аспектам зазначеної проблеми приділено увагу у працях Н. Коломінського, Є. Ходаківського та ін.

Науковці, зокрема Р.А. Фатхутдінов визначає управлінське рішення як результат аналізу, прогнозування, оптимізації, економічного обгрунтування і вибору альтернативи з багатьох варіантів досягнення конкретної мети системи менеджменту.

Формулювання цілей статті. Мета статті - розкрити сучасні вимоги до процесу прийняття управлінського рішення, визначити особливості, принципи та етапи.

Виклад основного матеріалу. Розробка ефективних управлінських рішень - необхідна умова забезпечення конкурентоспроможності продукції та організації на ринку, формування раціональних організаційних структур, проведення правильної кадрової політики, регулювання соціально-психологічних відносин в організації, створення позитивного іміджу. У загальному вигляді управлінське рішення (індивідуальне чи групове) визначає програму діяльності колективу по ефективному вирішенню проблеми, що склалася на основі знань об'єктивних законів функціонування керованої системи і аналізу інформації про її стан. Управлінські рішення від всіх інших рішень відрізняють:

Цілі. Суб'єкт управління приймає рішення виходячи не зі своїх власних потреб, а 3 метою вирішення проблем конкретної організації.

Наслідки. Менеджер, особливо високого рангу, вибирає напрям дій не тільки для себе, але і для організації в цілому і їі працівників. Його рішення можуть істотно вплинути на діяльність багатьох людей. Якщо організація велика і впливова, рішення іiі керівників можуть серйозно відбитися на соціально-економічній ситуації цілих регіонів. Наприклад, рішення закрити нерентабельну організацію може істотно підвищити рівень безробіття.

Поділ праці. В організації існує певний розподіл праці: одні працівники (менеджери) зайняті вирішенням виникаючих проблем і прийняттям рішень, а інші (виконавці) - реалізацією вже прийнятих рішень.

Професіоналізм. Процес управління організацією прийняття рішень вимагає професійної підготовки та відповідальності. Далеко не кожен співробітник організації має повноваження самостійно володіти певними професійними знаннями і навичками, самостійно приймати певні рішення [4].

Розглянувши особливості прийняття рішень в організаціях, можна дати наступне визначення управлінського рішення.

Управлінське рішення - це вибір альтернативи, здійснюваний особою, яка приймає рішення, в рамках його посадових повноважень і компетенцій, спрямований на досягнення цілей організації [5].

Прийняття рішення являє собою свідомий вибір з наявних варіантів чи альтернатив напрямку дій, що скорочують розрив між сьогоденням i майбутнім бажаним станом організації. Цей процес включає багато різних елементів, але неодмінно в ньому присутні проблеми, цілі, альтернативи. Даний процес лежить в основі планування діяльності організації, тому що план - це набір рішень по розміщенню ресурсів і напряму їх використання для досягнення організаційних цілей. 
Управління організацією прийняття рішень здійснюється менеджерами різних рівнів і носить досить формалізований характер, так як рішення стосується не однієї особистості, а підрозділу або організації в цілому. Як правило, рішення повинні прийматися там, де виникає проблемна ситуація, для цього менеджерів відповідного рівня необхідно наділити повноваженнями і покласти на них відповідальність за стан справ на керованому об'єкті. Дуже важливою умовою позитивного впливу рішення на роботу організації $€$ його узгодженість з раніше прийнятими рішеннями, як по горизонталі, так і по вертикалі управління [2].

Сформулюємо основні принципи прийняття управлінських рішень.

1. Принцип системності. Багато підприємств працюють, відчуваючи стресові ситуації, фінансові втрати, на них спостерігається демотивація співробітників. І все це тому, що прийняті рішення не були оптимальними.

2. Принцип стандартизації. Суть його полягає в тому, що більшість реальних управлінських ситуацій може буги зведена до набору так званих стандартних ситуацій, які детально розроблені, а дії керівника в цих випадках добре відомі з практики.

Тому необхідно вивчити можливості їх поділу на стандартну і нестандартну частини. Для нестандартної частини ситуації необхідний спеціальний аналіз 3 метою знаходження особливого для даного випадку рішення.

3. Принцип оптимальної інформованості. Раціональні управлінські рішення досяжні лише, коли їм відповідає достатня інформаційна база. Причому для кожного з управлінських рішень існує оптимальна інформаційна база.

4. Принцип автоматизмуреалізації управлінських рішень. Принцип полягає в тому, щоб прийняте керівником рішення автоматично доводилося до необхідного рівня і ставало практичним керівництвом до дії.

Щоб реалізувати цей принцип, необхідна система добре налагоджених і взаємопов'язаних управлінських механізмів. Якщо такі механізми відсутні або їх сукупність недостатня, будь-яке, навіть найкраще рішення, може залишитися нереалізованим.

5. Принцип обліку ймовірних наслідків. Раціональне управлінське рішення припускає облік ймовірних наслідків його реалізації.

6. Принцип свободи вибору. Якщо у людини (групи), що приймає рішення, немає або недостатньо умов для його вибору з безлічі можливих варіантів, то про ефективне вирішення не може йти мова. Керівник має заохочувати самостійність членів колективу, їх ініціативу.
7. Принцип відповідальності. Приймаючий рішення несе відповідальність за результати його реалізації. Це в рівній мірі відноситься і до колегіально ухваленого рішення [1].

8. Принциппропорційностіправі відповідальності. Даний принцип передбачає оптимальний розподіл обов'язків і відповідальності між керівником і виконавцем різного рівня, а саме: рівень відповідальності і ступінь компетентності особи, що приймає рішення, повинні відповідати змістуі рівню його функціональних обов'язків.

9. Принцип творчості. Творчість в управлінні не завжди високо цінувалося, але зараз це важлива цінність, i, ймовірно, іiі значення буде зростати. Особливо творчий підхід потрібен, коли наявні рішення не ефективні. Він необхідний для уточнення проблем і пошуку інноваційних ідей.

У процесі творчого вирішення проблем науковці виділяють п'ять стадій: 1) вивчення проблеми; 2) продукування ідей; 3) відсів застосованих ідей; 4) планування нововведень; 5) зворотний зв’ язок і аналіз.

10. Принцип своєчасності. Він орієнтує на вибір найкращого моменту для прийняття рішення для очікуваного ефекту.

11. Принцип єдності єдиноначальності і колегіальності. Єдиноначальність і колегіальність, на перший погляд, виключають одне одного. Перше передбачає персональну відповідальність за прийняття рішення, друге - колективну відповідальність. Однак насправді вони можуть бути вдало суміщені. Скажімо, керівник при підготовці рішення активно консультується 3 підлеглими (колегіальність) і з урахуванням їх думки приймає рішення, беручи на себе всю повноту відповідальності.

12. Принцип співучасті. Він означає активну й особисту участь у прийнятті рішення всіх членів колективу [3].

Процес прийняття рішень складний i багатосторонній. Він включає цілий ряд стадій $\mathrm{i}$ операцій. Питання, скільки і які стадії повинен пройти процес прийняття рішень, який конкретний зміст кожного з них, суперечливі і неоднаково вирішуються менеджерами. Це залежить від кваліфікації керівника, ситуації, стилю керівництва і культури навчального закладу. Важливо, щоб кожен менеджер розумів сильні сторони й обмеження кожного підходу та процедуру прийняття рішення і вмів вибирати кращий варіант 3 урахуванням ситуації і власного стилю управління.

Класичний підхід до прийняття управлінського рішення полягає в дотриманні певної процедури і виконанні обов'язкових дій. Незалежно від 
підходу, який обрала особа, що приймає рішення, існують визначені кроки, які вона проходить у процесі прийняття рішень. Процес може бути розбитий на шість кроків:

1) Визначення проблем.

Проблема складається в деяких відхиленнях від очікуваного ходу подій. Процес визначення проблеми полягає в її виявленні.

Виявлення проблеми - процес усвідомлення, що існує деякий вид проблеми. Джерела, з яких менеджер може довідатися про існування проблеми, містять у собі особистий огляд, аналіз даних і документів компанії, крім того, суспільна думка. Думка менеджерів і їхніх підлеглих також $€$ джерелом виявлення проблеми та визначення ступеня іiі важливості.

2) Постановка цілей.

3 визначення проблеми випливає постановка цілей, що будугь основою для майбугнього рішення.

3) Розробка альтернативних рішень.

Альтернативні рішення - два чи більше способів розгляду проблеми. Процес розробки альтернативних рішень проводиться для того, щоб знайти найкраще рішення, з огляду на всі фактори, які впливають на процес їх прийняття. Це допомагає запобігти вибору першого рішення. Замість того, щоб розглядатися окремо один від одного, варіанти рішень розглядаються разом.

Менеджери можуть спочатку оцінити одне рішення стосовно іншого, а потім вибрати краще 3 двох. Далі вони можуть повторити те ж саме 3 двома іншими. Потім два кращих обраних рішення порівнюються між собою і вибирається більш вигідне з цих двох. Ідея полягає в тому, щоб кожен варіант рішення був оцінений не тільки щодо мети, але й щодо інших варіантів.

Процес розробки альтернативних рішень - це пошук актуальної інформації з проблеми та її аналізу. Інформація може бути отримана 3 багатьох джерел, таких як незалежні експерти, управлінський апарат, спостереження за процесом ухвалення рішення, технічні публікації і документи, зібрані з власних звітів вищого навчального закладу [1].

4) Вибір альтернативи.

Ефективність альтернативи може бути визначена шляхом оцінки двох факторів: наскільки реальна альтернатива в умовах поставлених цілей i ресурсів організації і як добре вона зможе вирішити проблему. Менеджер повинен пам'ятати, що ідеальне на папері рішення проблеми може таким у дійсності і не виявитися. Вибираючи альтернативу, менеджери повинні спробувати мінімізувати ризик виникнення додаткових проблем.
Він повинен також визначити, як підлеглі будуть реагувати на дане рішення, яке може бути спірним. Але, оцінюючи альтернативу, можна довідатися про думку працівників та передбачити іiі ефект в інших сферах організації.

5) Реалізація альтернативи.

Вибір альтернативи передбачає іiі здійснення, тобто впровадження рішення в дію. Існує ряд факторів щодо реалізації рішення.

Оголошення альтернативи. Менеджер повідомляє рішення чітко і без сумніву. Якщо альтернатива цінна, вона буде підтримана.

Видача необхідних розпоряджень. Менеджер повинен обговорити обрану альтернативу 3 підлеглими і менеджерами, яких стосується виконання даного рішення. Розпорядження повинні віддаватися чітко, всі зміни пояснюватися.

Призначення специфічних завдань. Здійснення рішення передбачає безліч доручень різним людям, які вимагають значних змін у звичайній роботі. Часом вони передбачають нові доручення і завдання, що вимагає пояснення їх доцільності [2].

Розподіл ресурсів. Реалізація рішення може потягнути новий перерозподіл матеріальних і трудових ресурсів. Менеджер повинен усвідомлювати те, що багато ресурсів можуть знадобитися ще на стадії створення різних альтернатив.

Спостереження за процесом реалізації рішення. Менеджер повинен знати, чи виконується рішення належним чином згідно програми реалізації.

6) Оцінка результатів рішення.

Після того, як рішення реалізоване, менеджери повинні оцінити його ефективність.

Якщо рішення оцінене як неефективне, менеджер може вибрати іншу альтернативи чи створити новий список альтернатив. Якщо рішення оцінене як ефективне, менеджер повинен переглянути елементи, що зробили його таким. Досвід прийняття і здійснення кожного рішення стає безцінною частиною управлінського досвіду. Він буде використаний повторно для прийняття рішень у майбутньому.

Висновки. Діяльність будь-якої організації складається $з$ двох нероздільних процесів: процесу управління, який полягає в реалізації функцій планування, організації діяльності, мотивації, контролю, і керованого процесу, який складається з безлічі взаємозалежних операцій, спрямованих на досягнення цілей організації.

Процес управління - це діяльність керівників і адміністративного апарату, що складається в реалізації функцій управління організацією з метою забезпечення максимальної або необхідної 
ефективності керованого процесу. Керований процес - це сукупність функціональних процесів (виробництво, маркетинг, фінанси, робота 3 персоналом, дослідження і розробки), пов'язаних 3 виробництвом продукції або наданням послуг організації [3].

Мета управління полягає в забезпеченні максимальної або необхідної ефективності керованого процесу і досягається шляхом вироблення і здійснення керуючих впливів, які представляють собою дії керівників, спрямовані на зміну керованих факторів зовнішнього i внутрішнього середовища організації, а також на прийняття управлінського рішення.

Процес прийняття управлінських рішень перебуває під впливом великого числа факторів і складається з ряду етапів. Менеджер повинен не тільки своєчасно, а й правильно вирішувати проблеми, що виникають, вони можуть виявитися і в результаті аналізу підсумків роботи у минулому періоді.

На цьому етапі менеджер зосереджує свою увагу на виявленні основних (вузлових) проблем розвитку як у поточному, так і в майбутньому періоді. Його завдання - глибоко вникнути у динаміку змін і оцінити можливості трудового колективу і труднощі, що виникають, відібрати дійсно кардинальні проблеми, оцінити причини їх виникнення, уявити можливі наслідки того або іншого варіанту впливу. Буває і так, що проблема $\epsilon$, але вона ще не “визріла”. Іноді потрібно випередити події, усунути загострення ситуації. На другому етапі вивчаються обставини і формулюється ціль для правильного вирішення проблеми. Від цього залежить ефективність всієї подальшої діяльності. Це дуже складна справа, яка вимагає глибоких знань, досвіду, а також здатності передбачити майбутнє.

Після формування точної цілі нового рішення менеджер здійснює третій етап - збір інформації і визначення критеріїв оцінки проекту рішення. Для цього він залучає при необхідності відповідних фахівців, які обгрунтовують і розробляють всю необхіднуінформацію.

Критеріями оцінки бажаного варіанту рішення $\epsilon$ ефективність реалізації, простота досягнення поставленої цілі, ступінь врахування всієї виробничої ситуації, повнота використання ресурсів і виконання завдань у визначені строки, а також економічність виконання рішення.

Перспективи подальших розвідок у даному напрямі. Перспективи подальших розвідок щодо сучасних вимог до управлінського рішення ми вбачаємо у розробці моделі прийняття управлінського рішення у закладах вищої освіти згідно Закону України "Про освіту” та Концепції Нової української школи.

\section{ЛІТЕРАТУРА}

1. Шоробура I. М. Педагогічний менеджмент: курс лекцій. Кам'янець-Подільський: Зволейко Д.Г., 2010. 192 c.

2. Освітній менеджмент: навч. посібник для викладачів ін-тів післядипломної освіти, керівників загальноосвіт. навч. закл., слухачів курсів підвищ. кваліфікації / за ред.: Л. Даниленко, Л. Карамушки. К.: Шкільний світ, 2003. 400 с.

3. Шоробура I. М., Долинський Є. В., Долинська О. О. Менеджмент вищої освіти: навч. посіб. Хмельницький: ПП Заколодний М.I., 2015. $259 \mathrm{c}$.

4. Хміль Ф. Менеджмент: підруч. для студ. вуз. К: Академвидав, 2003. 607 с.

5. Осовська Г., Осовський О. Основи менеджменту: підруч. К.: Магнолія плюс; Львів: Новий світ, 2003. $334 \mathrm{c}$.

\section{REFERENCES}

1. Shorobura, I. M. (2010). Pedahohichnyi menedzhment: kurs lektsii [Pedagogical management: a course of lectures]. KamianetsPodilskyi: Zvoleiko D. H., 192 p. [in Ukrainian].

2. Danylenko, L. \& Karamushky, L. (Ed.). (2003). Osvitnii menedzhment: navch. posibnyk dlia vykladachiv in-tiv pisliadyplomnoi osvity, kerivnykiv zahalnoosvit. navch. zakl., slukhachiv kursiv pidvyshch. kvalifikatsii [Educational management: educational guide for teachers of Postgraduate Education Institutes, heads of the General Education Establishments, students who are doing the courses of qualifications]. Kyiv: Shkilnyi svit, 400 p. [in Ukrainian].

3. Shorobura, I. M., Dolynskyi, Ye. V. \& Dolynska, O.O. (2015). Menedzhment vyshchoi osvity: navch. posib. [Management of Higher Education: Educational manual]. Khmelnytskyi: PP Zakolodnyi M.I., 259 p. [in Ukrainian].

4. Khmil, F. (2003). Menedzhment: pidruch. dlia stud. vuz. [Management: A textbook for students of Higher Educational Establishments]. Kyiv: Akademvydav, 607 p. [in Ukrainian].

5. Osovska, H. \& Osovskyi, O. (2003). Osnovy menedzhmentu: pidruch. [Fundamentals of Management: A textbook]. Kyiv: Mahnoliia plius; Lviv: Novyi svit, 334 p. [in Ukrainian].

Стаття надійшла до редакції 31.07.2018 